\title{
Measles in adults: A comparison of hospitalised HIV-infected and HIV-uninfected patients
}

\begin{tabular}{|c|c|}
\hline \multicolumn{2}{|c|}{$\begin{array}{l}\text { Authors: } \\
\text { Nina E. Diana }{ }^{1,3} \text { (D) } \\
\text { Charles Feldman } 2,3\end{array}$} \\
\hline \multicolumn{2}{|c|}{$\begin{array}{l}\text { Affiliations: } \\
{ }^{1} \text { Division of Nephrology, } \\
\text { Department of Internal } \\
\text { Medicine, Charlotte Maxeke } \\
\text { Johannesburg Academic } \\
\text { Hospital, Johannesburg, } \\
\text { South Africa }\end{array}$} \\
\hline \multicolumn{2}{|c|}{$\begin{array}{l}{ }^{2} \text { Division of Pulmonology, } \\
\text { Department of Internal } \\
\text { Medicine, Charlotte Maxeke } \\
\text { Johannesburg Academic } \\
\text { Hospital, Johannesburg, } \\
\text { South Africa }\end{array}$} \\
\hline \multicolumn{2}{|c|}{$\begin{array}{l}{ }^{3} \text { Faculty of Health Sciences, } \\
\text { University of the } \\
\text { Witwatersrand, } \\
\text { Johannesburg, South Africa }\end{array}$} \\
\hline \multicolumn{2}{|c|}{$\begin{array}{l}\text { Corresponding author: } \\
\text { Nina Diana, } \\
\text { ninadiana1@gmail.com }\end{array}$} \\
\hline \multicolumn{2}{|c|}{$\begin{array}{l}\text { Dates: } \\
\text { Received: } 22 \text { June } 2018 \\
\text { Accepted: } 22 \text { Feb. } 2019 \\
\text { Published: } 13 \text { Aug. } 2019\end{array}$} \\
\hline \multicolumn{2}{|c|}{$\begin{array}{l}\text { How to cite this article: } \\
\text { Diana NE, Feldman C. } \\
\text { Measles in adults: A } \\
\text { comparison of hospitalised } \\
\text { HIV-infected and HIV- } \\
\text { uninfected patients. S Afr J } \\
\text { HIV Med. 2019;20(1), a877. } \\
\text { https://doi.org/10.4102/ } \\
\text { sajhivmed.v20i1.877 }\end{array}$} \\
\hline \multicolumn{2}{|c|}{$\begin{array}{l}\text { Copyright: } \\
\text { C 2019. The Authors } \\
\text { Licensee: AOSIS. This } \\
\text { is licensed under the } \\
\text { Creative Commons } \\
\text { Attribution License. }\end{array}$} \\
\hline \multicolumn{2}{|l|}{ Read online: } \\
\hline 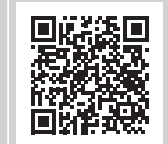 & $\begin{array}{l}\text { Scan this QR } \\
\text { code with your } \\
\text { smart phone or } \\
\text { mobile device } \\
\text { to read online. }\end{array}$ \\
\hline
\end{tabular}

Background: Although measles is traditionally a childhood illness, there are an increasing number of adult cases. Despite both measles and HIV infection being endemic in sub-Saharan Africa, there are little data regarding outcomes in co-infected patients.

Objectives: Compare demographic, clinical, laboratory and radiographic features, as well as outcome (length of hospital stay, complications and mortality) between HIV-infected and HIVuninfected adult patients admitted with confirmed measles.

Methods: We conducted a retrospective record review of adult patients with confirmed measles who were admitted to the Infectious Diseases Unit at the Charlotte Maxeke Johannesburg Academic Hospital during the peak of the 2009 and 2010 South African measles outbreak. The data collected included demographic, clinical and laboratory parameters, as well as outcomes.

Results: Of the 33 confirmed measles cases admitted, 24 patients were tested for HIV infection and 18 tested seropositive. There were no significant differences in the demographics, clinical findings or laboratory data when comparing the HIV-positive and HIV-negative cases. Serious clinical manifestations were seen more frequently in HIV-positive patients (odds ratio [OR] 5, 95\% confidence interval [CI] $0.48-51.8, p=0.34$ ). One of the six patients testing HIV-negative developed pneumonia, while six of the 18 HIV-positive patients had a course complicated by pneumonia. Five of these HIV-positive patients required admission to the intensive care unit, three developing respiratory failure necessitating mechanical ventilation. HIV-positive patients had several other manifestations, including acute kidney injury, purulent conjunctivitis, pancreatitis and encephalitis. HIV-positive patients had a significantly longer hospital stay $(p=0.03)$. There were three deaths in the HIV-positive group, but none in the HIV-negative group (OR 2.9, 95\% CI 0.13-65.3, $p=0.55$ ).

Conclusion: Our study provides data on the largest series of hospitalised adults infected with HIV and co-infected with measles. More severe consequences seemed to occur in hospitalised HIV-positive patients.

Keywords: Measles; Adults; Complications; Human immunodeficiency virus; Infectious diseases.

\section{Introduction}

Measles is one of the most contagious of all human viruses, ${ }^{1}$ and infects approximately 10 million people annually, with an estimated mortality of 134200 in 2015, occurring mainly in developing countries. ${ }^{2}$ Although it is historically a childhood illness, ${ }^{1}$ reports have highlighted an increasing frequency of measles occurring in young adults. ${ }^{3,4,5,6}$ With the incorporation of measles vaccination into routine childhood vaccination programmes, there has been a 'shift of disease burden'. It now occurs more commonly in older patients who missed vaccination as children.7,8 In addition, protection induced by the measles vaccine also seems to wane over a period of years (secondary vaccine failure), with the length of protection having been estimated to be approximately 25 years. ${ }^{9}$

Factors affirming the theory that the HIV epidemic may enhance dissemination of measles include the high rates of primary and secondary measles vaccine failure in HIV-infected persons, ${ }_{10,11,12,13,14}$ atypical presentations of measles resulting in delayed diagnosis in HIV-infected individuals, ${ }^{15,16}$ as well as the association of HIV infection with prolonged measles viral shedding and delayed clearance of the measles virus (MV). ${ }^{17}$ Serious complications have been described in HIV-positive patients co-infected with measles. . $1,19,20,21,22,23^{1}$

All studies comparing HIV-positive and HIV-negative patients infected with measles have been conducted in the paediatric population only. Moss et al. ${ }^{24}$ reported HIV-positive children to have 
a longer duration of illness $(p=0.03)$, a longer hospital stay $(p=0.0004)$ and a higher mortality $(p<0.01)$. However, in a report by Sension et al. ${ }^{25}$ from Kinshasa, there were similar rates of pneumonia, diarrhoea and death in the HIV-positive and HIV-negative children. In South Africa, there have been three studies comparing HIV-positive and HIV-negative children infected with measles. Morrow et al. ${ }^{26}$ concluded that although HIV-infected patients were 1.6 times more likely to be hospitalised, there was no difference in death rate between the two groups. Le Roux et al..$^{27}$ documented that the length of hospital admission was longer, the number of readmissions was greater and the odds ratio (OR) of death was seven times higher in the HIV-positive group. Pamacheche et al. ${ }^{28}$ described the clinical profile of children admitted with measles to a teaching hospital in Johannesburg. There were two deaths, both in children that were HIV-negative.

Between 2009 and 2011, an outbreak of measles occurred in South Africa that resulted in 18431 laboratory-confirmed cases being reported to the National Institute of Communicable Diseases of the National Health Laboratory Service. ${ }^{29}$ During this outbreak, a number of cases were admitted to the adult Infectious Diseases ward at the Charlotte Maxeke Johannesburg Academic Hospital (CMJAH) in Johannesburg and this afforded us the opportunity to describe the clinical features and outcome of adult patients with measles comparing the HIV-positive and HIV-negative cases.

\section{Methods}

This was a retrospective record review of adult patients with confirmed measles, who were admitted to the Infectious Diseases Unit (IDU) at the CMJAH during the peak of the 2009 and 2011 South African measles outbreak. The majority of cases occurred from week 37 in 2009 to week 24 in 2010. The study period was 29 September 2009 to 31 March 2010.

The data collected included all available demographic and clinical features and laboratory parameters. Patients with clinical features suggestive of measles were confirmed to have measles by serological testing, using the Enzygnost Anti-Measles Virus/IgM assay (Dade-Behring, Marburg, Germany). HIV testing, using a chemiluminescent microparticle immunoassay for the simultaneous qualitative detection of HIV p24 antigen and antibodies to HIV type 1 and / or type 2 (ARCHITECT HIVAb / Ag Combo Calibrator, Abbott Laboratories, Wiesbaden, Germany), was offered to all confirmed measles cases. The clinical characteristics and outcomes of these patients were compared in HIV-positive and HIV-negative cases. Outcome measures were length of hospital stay, complications and mortality.

The HIV-infected and HIV-uninfected groups were compared using the Mann-Whitney $U$ test for continuous variables, and the Fisher's exact (two-tailed) test for categorical variables. Analyses were done using GraphPad InStat version 3. A $p$-value $<0.05$ was considered to be statistically significant.

\section{Ethical consideration}

Permission to conduct the study was obtained from the Human Research Ethics Committee of the University of Witwatersrand (Clearance Certificate No. M10104).

\section{Results}

A total of 51 adult patients with suspected measles were admitted to the IDU of CMJAH between 29 September 2009 and 31 March 2010. Thirty-three (64.7\%) of these patients were confirmed to have measles by serology. In 12 patients $(23.5 \%)$, measles serology was negative and six patients $(11.8 \%)$ were not tested. Of the 33 patients confirmed to have measles by serology, $24(72.7 \%)$ consented to a test for HIV infection. These 24 patients were studied further. Figure 1 shows the study population included in this analysis.

Of the 24 patients, 13 were female and 11 were male. The mean (standard deviation) age of the HIV-positive group was 28.1 (5.6) years and of the HIV-negative group was 29.6 (9.0) years. Of the 24 patients, 18 patients (12 females) tested seropositive for HIV infection. Of the entire group, only one HIV-positive patient reported a measles contact and two patients in the HIV-positive cohort remembered previously being vaccinated against measles as a child.

Presenting features and examination findings are depicted in Tables 1 and 2. There were no significant differences between the two patient groups. The median duration of symptoms was 4 days (range: 1-7 days) in the HIV-positive group and 3 days (range: $3-6$ days) in the HIV-negative group.

Laboratory investigations also revealed no significant differences between the two groups (Table 3). In the HIVpositive group, the median CD4 count was 109 cells $/ \mathrm{mm}^{3}$ (range: $18-599$ cells $/ \mathrm{mm}^{3}$ ) (16 patients had data), the HIV viral load (VL) was available for seven patients (with a median of 15000 copies/mL) and three patients had a VL lower than the detectable limit. Eight patients (44.4\%) were newly diagnosed with HIV infection on this presentation and four patients were already on highly active antiretroviral therapy.

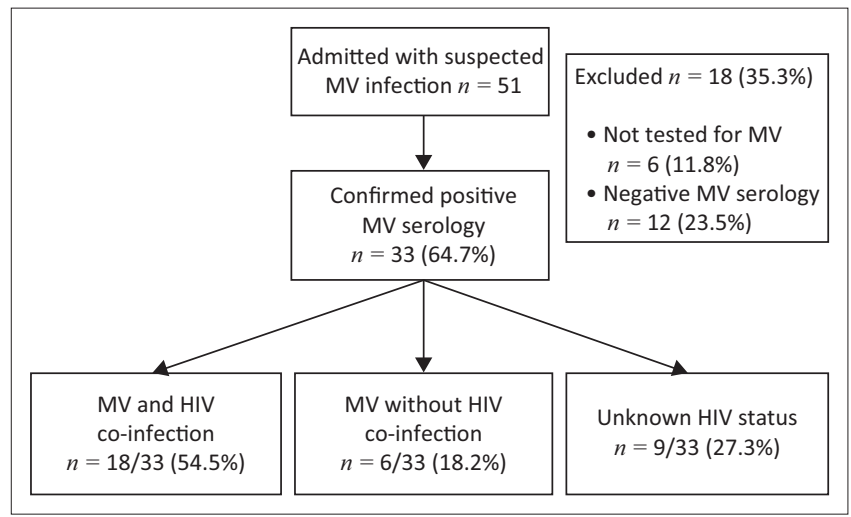

$\mathrm{MV}$, measles virus.

FIGURE 1: Flow diagram of the study patients. 
Serious clinical manifestations were seen more frequently in HIV-positive than HIV-negative patients (OR 5, 95\% confidence interval [CI] 0.48-51.8, $p=0.34$ ). One of the six patients testing HIV-negative developed pneumonia, while six of the $18 \mathrm{HIV}$-positive patients had a clinical course complicated by pneumonia (OR 2.5, 95\% CI 0.23-26.5, $p=0.63$ ). Five of these HIV-positive patients required admission to the intensive care unit or high care unit, three developing respiratory failure necessitating mechanical ventilation. These three patients also developed acute kidney injury. HIV-positive patients had several other

TABLE 1: Presenting symptoms in 24 adult patients with measles: Comparison of HIV-positive and HIV-negative cases.

\begin{tabular}{|c|c|c|c|c|c|c|c|}
\hline \multirow[t]{2}{*}{ Presenting symptom } & \multicolumn{3}{|c|}{ HIV-positive patients } & \multicolumn{3}{|c|}{ HIV-negative patients } & \multirow[t]{2}{*}{$p$} \\
\hline & $n$ & $N \dagger$ & $\%$ & $n$ & $N \dagger$ & $\%$ & \\
\hline Fever & 17 & 18 & 94.4 & 6 & 6 & 100 & 1.0 \\
\hline Rash & 18 & 18 & 100 & 6 & 6 & 100 & 1.0 \\
\hline Red eyes or conjunctivitis & 18 & 18 & 100 & 6 & 6 & 100 & 1.0 \\
\hline Coryza & 9 & 18 & 50 & 3 & 6 & 50 & 1.0 \\
\hline Cough & 11 & 18 & 61.1 & 6 & 6 & 100 & 0.13 \\
\hline Shortness of breath & 2 & 18 & 11.1 & 0 & 6 & 0 & 1.0 \\
\hline Vomiting & 3 & 16 & 18.8 & 3 & 4 & 75 & 0.06 \\
\hline Diarrhoea & 2 & 17 & 11.8 & 0 & 4 & 0 & 1.0 \\
\hline Abdominal pain & 1 & 17 & 5.9 & 0 & 4 & 0 & 1.0 \\
\hline Headache & 1 & 18 & 5.6 & 2 & 6 & 33.3 & 0.22 \\
\hline
\end{tabular}

$\dagger, n$ denotes the number of patients in whom the symptom was present; $N$ is the number of patients in whom the presence or absence of the symptom was recorded. manifestations, including purulent conjunctivitis, pancreatitis and encephalitis (Table 4).

HIV-positive patients had a significantly longer hospital stay $(p=0.03)$. There were three deaths in the HIV-positive group, but none in the HIV-negative group. The OR of death was 2.9 times higher in the HIV-positive group (OR 2.9, 95\% CI 0.13-65.3, $p=0.55)$.

\section{Discussion}

In this study, there were no differences in demographic, clinical and laboratory parameters when comparing the

TABLE 4: Complications in 24 adult patients with measles: Comparison of HIV-positive and HIV-negative cases.

\begin{tabular}{|c|c|c|c|c|c|}
\hline \multirow[t]{2}{*}{ Complication } & \multicolumn{2}{|c|}{$\begin{array}{c}\text { HIV-positive } \\
\text { patients }(N=18)\end{array}$} & \multicolumn{2}{|c|}{$\begin{array}{l}\text { HIV-negative } \\
\text { patients }(N=6)\end{array}$} & \multirow[t]{2}{*}{$p$-value } \\
\hline & $n$ & $\%$ & $n$ & $\%$ & \\
\hline Any complication & 9 & 50.0 & 1 & 16.7 & 0.34 \\
\hline Pneumonia & 6 & 33.3 & 1 & 16.7 & 0.63 \\
\hline ICU/ high care admission & 5 & 27.8 & 0 & 0 & 0.28 \\
\hline Respiratory failure & 3 & 16.7 & 0 & 0 & 0.55 \\
\hline Mechanical ventilation & 3 & 16.7 & 0 & 0 & 0.55 \\
\hline Acute kidney injury & 3 & 16.7 & 0 & 0 & 0.55 \\
\hline Purulent conjunctivitis & 1 & 5.6 & 0 & 0 & 1 \\
\hline Pancreatitis & 1 & 5.6 & 0 & 0 & 1 \\
\hline Encephalitis & 1 & 5.6 & 0 & 0 & 1 \\
\hline
\end{tabular}

TABLE 2A: Examination findings in 24 adult patients with measles: Comparison of HIV-positive and HIV-negative cases.

\begin{tabular}{|c|c|c|c|c|c|c|c|c|c|c|}
\hline \multirow[t]{2}{*}{ Vital signs } & \multirow[t]{2}{*}{ Sub-indicator } & \multicolumn{4}{|c|}{ HIV-positive patients $(N=18)$} & \multicolumn{4}{|c|}{ HIV-negative patients $(N=6)$} & \multirow[t]{2}{*}{$p$-value } \\
\hline & & Median & Range & $\bar{x}$ & s.d. & Median & Range & $\bar{x}$ & s.d. & \\
\hline Temperature $\left({ }^{\circ} \mathrm{C}\right)$ & - & 39 & $37.5-40$ & - & - & 39 & $37-39$ & - & - & 0.1 \\
\hline \multirow[t]{2}{*}{ Blood pressure (mmHg) } & Systolic & 103.5 & $90-149$ & - & - & 123.5 & $103-129$ & - & - & 0.13 \\
\hline & Diastolic & 69.5 & 40-99 & - & - & 75 & $67-79$ & - & - & 0.42 \\
\hline Heart rate (beats/min) & - & - & - & 124 & 23 & - & - & 105 & 23 & 0.1 \\
\hline
\end{tabular}

TABLE 2B: Examination findings in 24 adult patients with measles: Comparison of HIV-positive and HIV-negative cases.

\begin{tabular}{|c|c|c|c|c|c|c|}
\hline \multirow[t]{2}{*}{ Clinical features } & \multirow[t]{2}{*}{ Sub-indicator } & \multicolumn{2}{|c|}{ HIV-positive patients $(N=18)$} & \multicolumn{2}{|c|}{ HIV-negative patients $(N=6)$} & \multirow[t]{2}{*}{$p$-value } \\
\hline & & $n$ & $\%$ & $n$ & $\%$ & \\
\hline Rash & - & 18 & 100 & 6 & 100 & 1.00 \\
\hline Conjunctivitis & - & 18 & 100 & 6 & 100 & 1.00 \\
\hline Koplik spots & - & 5 & 27.8 & 1 & 16.7 & 1.00 \\
\hline Oral thrush & - & 6 & 33.3 & 0 & 0 & 0.28 \\
\hline Lymphadenopathy & - & 6 & 33.3 & 2 & 33.3 & 1.00 \\
\hline Confusion & - & 3 & 16.7 & 0 & 0 & 0.55 \\
\hline \multirow[t]{2}{*}{ Chest examination } & Crackles & 5 & 27.8 & 1 & 16.7 & 1.00 \\
\hline & Bronchial breathing & 1 & 5.6 & 0 & 0 & 1.00 \\
\hline
\end{tabular}

TABLE 3: Laboratory findings in 24 adult patients with measles: Comparison of HIV-positive and HIV-negative cases.

\begin{tabular}{|c|c|c|c|c|c|c|c|c|c|}
\hline \multirow[t]{2}{*}{ Findings } & \multicolumn{4}{|c|}{ HIV-positive patients $(n=18)$} & \multicolumn{4}{|c|}{ HIV-negative patients $(n=6)$} & \multirow[t]{2}{*}{$p$-value } \\
\hline & Median & Range & $\overline{\mathbf{x}}$ & s.d. & Median & Range & $\overline{\mathbf{x}}$ & s.d. & \\
\hline White cell count (cells $\left.\times 10^{9} / 1\right) \dagger$ & 6.6 & $4-14.8$ & - & - & 6.9 & $5.8-16$ & - & - & 0.40 \\
\hline Haemoglobin (g/dl) & 13.1 & $9.3-16.3$ & - & - & 16.5 & $9.6-17.4$ & - & - & 0.11 \\
\hline Platelets (cells x $10^{9} /$ ) & - & - & 187.7 & 53.9 & - & - & 183.0 & 49.9 & 0.87 \\
\hline Sodium (mmol/l) & 135.5 & $122-140$ & - & - & 132.5 & $126-141$ & - & - & 0.24 \\
\hline Potassium (mmol/l) & - & - & 4.0 & 0.6 & - & - & 4.0 & 0.6 & 0.97 \\
\hline Bicarbonate (mmol/l) & - & - & 21.7 & 3.4 & - & - & 23.8 & 3.5 & 0.23 \\
\hline Creatinine $(\mu \mathrm{mol} / \mathrm{l})$ & - & - & 117.9 & 55.2 & - & - & 100.5 & 45.7 & 0.46 \\
\hline Albumin (g/l) & - & - & 36.1 & $6.2 \dagger$ & - & - & 34.3 & $6.7 \ddagger$ & 0.65 \\
\hline CRP (mg/l) & - & - & 120.8 & $74.9 \dagger$ & - & - & 110.6 & $58.5 \rrbracket$ & 0.76 \\
\hline
\end{tabular}

$\dagger$, number of cases with available data $=17$.

\pm , number of cases with available data $=4$.

I, number of cases with available data $=5$. 
HIV-positive and HIV-negative groups. There was a tendency for complications to be more common in the HIV-positive group; however, the only significant difference was a longer length of hospital stay.

Over the 6-month period, 51 adult patients were admitted with suspected MV infection. Despite having clinical features suggestive of MV infection, 12 (23.5\%) patients had negative MV serology. Negative serological testing may be attributed to possible laboratory error, to patients not having mounted an adequate immune response because of underlying immunocompromise or to undetectable antibody levels within the first $72 \mathrm{~h}$ of the exanthem appearing. ${ }^{30}$

Of the 13 females who consented to HIV serological testing, 12 tested HIV-positive. There were twice as many females as males in the subgroup infected with HIV. This may reflect the burden of HIV infection among women in the South African population. ${ }^{31}$

In 2012, the estimated adult (15-49 years) prevalence rate of HIV and/or AIDS in South Africa was $18.8 \% .{ }^{31}$ However, in our study the prevalence of HIV-positivity was 18 of 24 patients (75\%). This higher rate of HIV infection among our measles cases may be the result of HIV-infected patients being at increased risk of acquiring measles and requiring hospitalisation ${ }^{26}$; firstly because HIV-induced immune deficiencies are compounded with the immune-suppressive effect of the MV and secondly because of an inferior response to measles vaccination. ${ }^{10,11,32,33,34,35}$

Presenting symptoms, findings on clinical examination and laboratory results revealed no significant differences between the HIV-infected and HIV-uninfected subgroups. All of the patients infected with HIV presented with features typical of MV infection, including the occurrence of a morbilliform rash. This contrasts with published data documenting atypical findings in HIV-infected patients. ${ }^{15,16}$ Furthermore, this is also despite the median CD4 cell count of 109 cells/ $\mathrm{mm}^{3}$ in the HIV-infected subgroup, suggesting advanced retroviral disease and immunosuppression.

Measles is typically a self-limiting illness, but individuals who are immunocompromised are at increased risk of severe disease. ${ }^{24}$ This was mirrored in our study as half of the HIVinfected adults in our cohort developed complications related to MV infection, as compared to only one patient in the HIVuninfected subgroup (OR $=5,95 \%$ CI $0.48-51.8, p=0.34$ ). The length of hospital stay was significantly higher in the HIVinfected subgroup $(p=0.03)$. All three deaths recorded in our cohort occurred in the HIV-infected subgroup (OR $=2.9,95 \% \mathrm{CI}$ $0.13-65.3, p=0.55)$, resulting in a case fatality rate of $16.7 \%$ in this group.

Possible limitations of this study include the following. Firstly, there were small patient numbers and this may have limited our ability to show statistical significance in some of the endpoints. Secondly, it was a retrospective study and so the datasets were not complete. Thirdly, we included only patients confirmed to have measles on serological testing, thus excluding 12 cases with clinical features of measles that tested negative for measles by serology and which may have represented false-negative cases because of HIV co-infection with deficient antibody synthesis. Fourthly, only patients with more severe disease were included as they were hospitalised patients. Lastly, the cases were all from a single centre, and therefore the results may not be generalisable. However, our study provides data on the largest series of hospitalised adults infected with HIV and co-infected with measles. Unlike other published literature, we were also able to provide a comparison of adult patients infected and uninfected with HIV, within the same cohort.

\section{Conclusion}

Our findings confirm that MV is still an important cause of morbidity and mortality, even among adult patients. Coinfection with HIV may be associated with worse outcomes. Future studies with larger patient numbers may substantiate this conclusion. HIV testing should be carried out in all adults with suspected MV infection. 'Mop-up' vaccination campaigns should perhaps also target adults infected with HIV with the aim of attaining protective antibody levels and reducing the risk of developing disease.

\section{Acknowledgements Competing interests}

The authors have no conflict of interests.

\section{Authors' contributions}

N.E.D. conducted the study and wrote the manuscript. C.F. supervised the study and reviewed the manuscript. All authors have read and approved the final manuscript.

\section{Funding Information}

This research received no specific grant from any funding agency in the public, commercial or not-for-profit sectors.

\section{Data availability statement}

Data sharing is not applicable to this article as no new data were created or analysed in this study.

\section{Disclaimer}

The views expressed in the article are those of the authors and not an official position of the institution or funder.

\section{References}

1. Babbott Jr FL, Gordon JE. Modern measles. Am J Med Sci. 1954;228(3):334-361. https://doi.org/10.1097/00000441-195409000-00013

2. WHO/UNICEF. WHO/UNICEF Joint Annual Measles Report, WHO Factsheet [homepage on the Internet]. 2017 [cited April 2017]. Available from: www.who. int/mediacentre/factsheet/fs286/en/

3. Takla A, Wichmann O, Rieck T, Matysiak-Klose D. Measles incidence and reporting trends in Germany, 2007-2011. Bull World Health Org. 2014;92:742-749. https:// doi.org/10.2471/BLT.13.135145 
4. Chao M, Shaohong $\mathrm{Y}$, Qiru S, et al. Measles transmission among adults with spread to children during an outbreak: Implications for measles elimination in China, 2014. Vaccine. 2016;34(51):6539-6544. https://doi.org/10.1016/j.vaccine.2016.02.051

5. Ogbuanu IU, Muroua C, Allies $M$, et al. Measles outbreak reveals measles susceptibility among adults in Namibia, 2009-2011. S Afr Med J. 2016;106(7): 715-270. https://doi.org/10.7196/SAMJ.2016.v106i7.10651

6. Stahl JP, Salmon D, Bruneel F, et al. Adult hospitalized for measles in France, in the 21st century. Med Mal Infect. 2013;43(10):410-416. https://doi.org/10.1016/j. medmal.2013.07.001

7. Schuster M, Stelzer T, Burckhardt F. Why are young adults affected? Estimating measles vaccination coverage in 20-34 year old Germans in order to verify progress towards measles elimination. PLoS Curr. 2015;25:7. https://doi.org/ 10.1371/currents.outbreaks.0a2d3e9465f067a0b2933d598d504d2e

8. Goodson JL, Masresha BG, Wannemuehler K, Uzicanin A, Cochi S. Changing epidemiology of measles in Africa. J Infect Dis. 2011;204(Suppl 1):S205-S214. https://doi.org/10.1093/infdis/jir129

9. Dine MS, Hutchins SS, Thomas A, Williams I, Bellini WJ, Redd SC. Persistence of vaccine-induced antibody to measles $26-33$ years after vaccination. J Infect Dis. 2004;189(Suppl 1):S123-S130. https://doi.org/10.1086/380308

10. De Milito A, Nilsson A, Titanji K, et al. Mechanisms of hypergammaglobulinaemia and impaired antigen-specific humoral immunity in HIV-1 infection. Blood. 2004;103(6):2180-2186. https://doi.org/10.1182/blood-2003-07-2375

11. Rudy BJ, Rutstein RM, Pinto-Martin J. Responses to measles immunization in children infected with human immunodeficiency virus. J Pediatr. 1994;125(1):72-74. https://doi.org/10.1016/S0022-3476(94)70125-3

12. Al-Attar I, Reisman J, Muehlmann M, McIntosh K. Decline of measles antibody titres after immunization in human immunodeficiency virus - Infected children. Pediatr Infect Dis J. 1995;14(2):149-151. https://doi.org/10.1097/00006454-199502000-00013

13. Kemper CA, Zolopa AR, Hamilton JR, Fenstersheib M, Bhatia G, Deresinski SC Prevalence of measles antibodies in adults with HIV infection: Possible risk factors for measles seronegativity. AIDS. 1992;6(11):1321-1325. https://doi.org/10.1097/ 00002030-199211000-00013

14. Palumbo P, Hoyt L, Demasio K, Oleske J, Connor E. Population-based study of measles and measles immunization in human immunodeficiency virus-infected children. Pediatr Infect Dis J. 1992;11(12):1008-1014. https://doi.org/10.1097/ 00006454-199211120-00004

15. Markowitz LE, Chandler FW, Roldan ED, et al. Fatal measles pneumonia without rash in a child with AIDS. J Infect Dis. 1988;158(2):480-483. https://doi.org/ 10.1093/infdis/158.2.480

16. Kaplan LJ, Daum RS, Smaron M, McCarthy CA. Severe measles in immunocompromised patients. JAMA. 1992;267(9):1237-1241. https://doi. org/10.1001/jama.267.9.1237

17. Permar SR, Moss WJ, Ryon JJ, et al. Prolonged measles virus shedding in human immunodeficiency virus-infected children, detected by reverse transcriptasepolymerase chain reaction. J Infect Dis. 2001;183(4):532-538. https://doi. polymerase chain reac
org/10.1086/318533

18. Nadel S, McGann K, Hodinka RL, Russtein R, Chatten J. Measles giant cell pneumonia in a child with human immunodefiency virus infection. Pediatr Infect Dis J. 1991;10(7):542-544. https://doi.org/10.1097/00006454-199107000-00014

19. Okamura A, Itakura O, Yoshioka M, Kubota M, Kikuta H, Kobayashi K. Unusual presentation of giant cell pneumonitis in a patient with acquired immunodeficiency syndrome. Clin Infect Dis. 2001;32(3):E57-E58. https://doi.org/10.1086/318499
20. Koppel BS, Poon TP, Khandji A, Pavlakis SG, Pedley TA. Subacute sclerosing panencephalitis and acquired immunodeficiency syndrome: Role of electroencephalopathy and magnetic resonance imaging. I Neuroimaging. 1996;6(2):122-125. https://doi.org/10.1111/jon199662122

21. Mustafa M, Weltman SD, Winick NJ, Bellini WJ, Timmons CF, Siegel JD. Subacute measles encephalitis in the young immunocompromised host: Report of two cases diagnosed by polymerase chain reaction and treated with ribavirin and review of diagnosed by polymerase chain reaction and treated with ribavirin and review of
literature. Clin Infect Dis. 1993;16(5):654-660. https://doi.org/10.1093/clind/16.5.654

22. Piastra $M$, Onesimo $R$, De Luca $D$, et al. Measles-induced respiratory distress, airleak and ARDS. Eur J Clin Microbiol Infect Dis. 2010;29(2):181-185. https://doi. org/10.1007/s10096-009-0838-x

23. Kija E, Ndondo A, Spittal G, Hardie DR, Eley B, Wilmshurst JM. Subacute sclerosing panencephalitis in South African children following the measles outbreak between 2009 and 2011. S Afr Med J. 2015;105(9):713-718. https://doi.org/ 10.7196/SAMJnew.7788

24. Moss WJ, Fisher C, Scott S, Monze M, Ryon J, Quinn T. HIV type 1 infection is a risk factor for mortality in hospitalized Zambian children with measles. Clin Infect Dis. 2008;46(4):532-537. https://doi.org/10.1086/526525

25. Sension MG, Quinn T, Markowitz LE, et al. Measles in hospitalized African children with human immunodeficiency virus. Am J Dis Child. 1988;142(12):1271-1272. https://doi.org/10.1001/archpedi.1988.02150120025021

26. McMorrow ML, Gebremedhin G, Van der Heever J, et al. Measles outbreak in South Africa, 2003-2005. S Afr Med J. 2009;99(5):314-319. https://doi.org/ 10.7196/SAMJ.2750

27. Le Roux DM, Le Roux SM, Nuttall J, Eley BS. South African measles outbreak 20092010 as experienced by a paediatric hospital. S Afr Med J. 2012;102(9):760-764. https://doi.org/10.7196/SAMJ.5984

28. Pamacheche TM. A description of the clinical profile and case management of paediatric patients admitted with measles to the Charlotte Maxeke Johannesburg Academic Hospital [homepage on the Internet]. [cited November 2014]. Available from: http://wiredspace.wits.ac.za/handle/10539/14305

29. Ntshoe GM, McAnerney JM, Archer BN, et al. Measles outbreak in South Africa: Epidemiology of laboratory confirmed cases and assessment of intervention, 20092011. PLoS One. 2013:8(2):e55682. https://doi.org/10.1371/journal.pone.0055682

30. Helfand RF, Kebede S, Mercader S, Gary HE Jr, Beyene H, Bellini WJ. The effect of timing of sample collection on the detection of measles-specific IgM in serum and oral fluid samples after primary measles vaccination. Epidemiol Infect. 1999;123(3):451-456. https://doi.org/10.1017/s0950268899002988

31. Simbayi LC, Shisana O, Rehle T, et al. South African national HIV prevalence, incidence and behaviour survey, 2012. Cape Town: HSRC Press; 2014.

32. Kerdiles YM, Sellin $\mathrm{Cl}$, Druelle J, Horvat B. Immunosuppression caused by measles virus: Role of viral proteins. Rev Med Virol. 2006;16(1):49-63. https://doi.org/ $10.1002 / \mathrm{rmv} .486$

33. Griffin DE. Measles virus-induced suppression of immune responses, Immuno Rev. 2010;236(1):176-189. https://doi.org/10.1111/j.1600-065x.2010.00925.x

34. Avota E, Gassert E, Schneider-Schaulies S. Measles virus-induced immunosuppression: From effectors to mechanisms. Med Microbiol Immunol. 2010;199(3):227-237. https://doi.org/10.1007/s00430-010-0152-3

35. Arpadi SM, Markowitz LE, Baughman AL, et al. Measles antibody in vaccinated human immunodeficiency virus type 1 - Infected children. Pediatrics. 1996;97(5): 653-657. 